\title{
Historical Geography of Antioch - The Queen of the East: Through Arab Travelers
}

\author{
Abdullah Balciogullari
}

\begin{abstract}
The travelers who have been travelling around the world by the motivation of trade, journey or mere curiosity, have indited the places they had visited. The Arab travelers could not by pass Antioch, which was a very significant city, in their journey to Anatolia or Damascus. In this study, fifteen handwritten itineraries were reached and studied in order to exhibit Antioch, the queen of East in the Ancient History, through the eyes of Arab travelers. Antioch has always found a special section in travel books with her ramparts and castles, streets, temples, bazaars and landmarks. Many travelers such as Al- Tabari, Al-Mas'udi, Al-Idrisi, Ibn Batuta, Al-Bakri al Andalousie, Yaqut al-Hamawi, Al-Qazwini and Abd alMu'min al-Bagdhadi have visited the city and wrote down what they have observed. The length and magnificence of the ramparts were the most impressive aspect of the city as well as the weather and the abundance of water, hammams and also the churches as being a religious center.

According to the travel books, the travelers agreed that Antioch was one of the most significant and magnificent cities of the era between 9th and 14th centuries in both Rome and Islamic world.
\end{abstract}

Index Terms-Antioch, historical geography, Arab travelers, travel book.

\section{INTRODUCTION}

Antakya, also known as Antioch, Antioch-on-the-Orontes is the capital of Hatay Province, in southern Turkey. Antakya is located on the banks of the Orontes River. The city is in a valley surrounded by mountains, the Amanos Mountains to the north and Mount Keldag, Mount Habib anNajjar (ancient Silpius) forming its eastern limits.

Antioch is a substantially old city which has been mentioned through the history of the humankind. Its climate, fertile fields and location being in the intersection of trade routes have made Antioch always a very important city [1]. Being the capital city in Hellenistic Period, being the Queen of East during the Roman Empire, and an important center of Christianity, today Antioch is a city where different ethnic and religious groups can live in peace.

It was the third largest city of the Roman Empire right after Rome and Alexandria and the center of the civilization and the religion. Around $40 \mathrm{AD}$, Barnabas, Pavlos and Petrus who were the apostles of Jesus, came to Antioch and spread the Christianity from here to all around Roman world [2]. Besides, the term Christian was firstly ever used in this city for the followers of Jesus which makes it more

Manuscript received April 9, 2015; revised June 26, 2015.

A. Balciogullari is with Çukurova University, Turkey (e-mail: abalci@cu.edu.tr). important religiously [3]. Since it has been a holy place like Jerusalem and Rome for Christian world, The St. Pierre Church was accepted as pilgrimage place by Pope in 1963 [4].

The travel books have been unique written resources since they reveal very special and secret information for the researchers in fields like geography, history and literature. In ancient times, when the communication tools were limited, the travel books served as the means of communication to transact the scientific and cultural developments [5]. Geography which consists of the terms the Earth and Depiction was applied through writing the information on the Earth by its nature [6]. The travel books can be considered as one of the most important of these applications. As being the primary source of information in historical geography studies, the travel books reveal information in different kinds of specifications that cannot be found in the formal historical documents [7].

In the Middle Age, Muslim scientists have continued and developed scientific methods and traditions of previous cultures. In that era, many scientific books were written in the field of geography just like all other fields of science. Many Muslim scientists had traveled from Spain to India and Africa and then to China and Russia and they had observed and described the places they have visited complying with the Geography sense of their times [8]. Arab geographers, travelers, and merchants have written masterpieces that can be used as primary resources in the field of Geography. Especially during $7^{\text {th }}$ to $14^{\text {th }}$ centuries, geography was the field of science that Muslim scientists were rather interested [9].

Antioch was founded by one of the generals of Alexander the Great, the king of Syria Selevkos I Nikator in 300 BC, and named as Antioch by him. The city was the third largest city of East Roman Empire and it was mentioned as "Orientis Opicum Pulcrum (The Queen of the East)" in the Latin manuscripts of that period [10]. It is also one of the pilgrimage centers of the world and also hosts a very significant mosaic museum. Today it is the center of social and religious tolerance as well as the most authentic city of Mediterranean culture.

\section{METHOD}

The purpose of this study is to exhibit the historical geography of Antioch through the eyes of Arab travelers by examining their travel books written in Arabic between the $9^{\text {th }}$ and the $14^{\text {th }}$ centuries. For this purpose, the travel books of Arab travelers covering from the $9^{\text {th }}$ to the $14^{\text {th }}$ centuries were examined and parts related to Antioch were quoted. A 
view of Antioch as it was approximately a thousand years ago was tried to be revealed by using various resources.

Since this study was aimed to depict and describe the conditions in the past as it was occurred, the research model was determined as a descriptive survey model. The document study method of qualitative research methods was used in this study. According to Yildirim and Simsek [11]; the document study includes the analysis of written materials about the target case or cases. In the qualitative research, when it is impossible to conduct direct observation or interview or when it is aimed to increase the validity of the research, written or visual materials can be included to the study besides the direct observation and interview.

In order to conduct this study, the facsimile or photographs of the handwritten travel books written in Arabic between the $9^{\text {th }}$ and $14^{\text {th }}$ centuries were reached and the sections about Antioch were selected among them in order to gather information about Antioch of at those times. Some of this information was transferred directly.

\section{FINDINGS}

\section{A. The Foundation of Antioch and Its Ramparts}

The city was founded around $300 \mathrm{BC}$ by Seleucus Nicator who was one of the generals of Alexander the Great. According to the ancient resources, with the population of three hundred thousand, Antioch was the third largest city of the Roman Empire and fourth largest city of the world. Seleucus founded the city in the piedmont of Silpius Mountain (Habib al- Najjar Mountain) and beside the Orontes River (Asi) and he named it after his father Antiochus. Selevkos I. Nikator who had founded his kingdom on the vast lands from Syria to India, had also founded 14 cities in the name of Antioch. Today only Antioch subject of this study still bears this name in the world [12].

The ramparts which were built by Seleucus I. Nicator simultaneously with the city, lied through the peak of Silpius (Habib-i Neccar) down to the plains to the river Asi and completely surrounded the city. The length of the ramparts was up to 23.600 meters and there were paths to walk on them. Owing to those paths, it was possible to walk all around the city. There were 360 multi-story squareshaped bastions on these ramparts with a distance of one arrow shot. Each bastion had gates made of iron just like castle gates. These bastions had five stories and whereas the bottom floors were for animals, the top floors were for watchmen and soldiers. Before they were demolished, there were gates in these ramparts that open to various directions (like Alexandria, Aleppo, Defne, Kuseyr). The most important one of those gates was the Bridge Gate which was located on the Asi River and was the only entrance of roads from the north. There was also an internal castle on the highest point of Habib-i Neccar Mountain.

The ramparts, which had been standing with all their magnificiency, had survived many attacks and earthquakes during the 10 th, 11 th and $12^{\text {th }}$ centuries, which were described in details and same manner by each Arab traveler that came to Antioch. Most of them revealed very similar information. Al-Mas udi $^{1}$ is the one that gave the name of the founder of the city and revealed details about the city, ramparts, and castle. He stated that [13] "Antiochos has got the city built" and gave us this information about the city and the ramparts."He has got built the most remarkable building that lies to the mountains and plains. The length of the ramparts is 12 miles. The number of bastion is 136. The number of balconies on the ramparts is 24 thousands. He also got built gates for each bastion large enough for the entrance of men and their horses and in addition he also has got built higher towers for each bastion. There were shelters for animals at bottom floors of the bastions and there were places to stay for the men at the top floors. Each bastion also has an iron gate like a separate castle. The marks and remains of those iron gates are still here (that was the year of 332)"”.

The ramparts of city of Antioch were protected by the mercenaries whose center was in Istanbul. The contract with these mercenaries was renewed each year. Al-Qazwin ${ }^{2}$ gave accurate numbers about the ramparts of Antioch [14].

The ramparts have various sections. They have 360 bastions. 4000 soldiers who are controlled by Constantine protect these ramparts. The mission to protect the ramparts is hired out for one year and the contract is renewed for the next year. The ramparts are one of the most interesting constructions of the world as they lie from the river banks to the top of the mountains.

The bastions of the ramparts of Antioch were studied by Al-Qazwini ${ }^{3}$ in detail and both the castle and the features of the bastions were indited in details [14].

The perimeter is 12 miles. Each bastion has paths which provide connection both for the city dwellers and also the people working for the castle to its environment. In addition, he has got built a bottom floor for horses and a top floor for horsemen in each bastion. Each bastion looks like a castle and it has an iron gate. At the very top floor, there is a residence for the patriarch. There is no entrance anyway to this castle from outside. The city has a circular shape as it lies as half of it on the plain and half of it on the mountain. There is a huge castle located on an extremely high point up on the mountain which can be seen from a very long distance. This castle prevents the sub to rise on the city earlier. The Sun can be seen in the city only after $2 \mathrm{pm}$.

Yaqut al-Hamaw ${ }^{4}$ stated in his travel book that the ramparts that surrounded Antioch reached to the tops of the mountain Habib Neccar where the city leaned its back and also there was a castle on the top that be seen from a very long distance. In addition, as we learned from Al- Hamavi, there were five entrances on the ramparts of the city. However he did not provide any information about the names or to where these gates open [15].

While giving information about the ramparts of Antioch

\footnotetext{
${ }^{1}$ Al-Masudi, v.1 pp. 202, 228, 234, 235

${ }^{2}$ Al-Qazwini, pp. 101

${ }^{3}$ Al-Qazwini, pp.100-101

${ }^{4}$ Yaqut al-Hamawi, v. 1, pp. 267
} 
Al-Idrisi ${ }^{5}$ mentioned that they were 12 miles and they were made of hewn stone. He also added that there are gardens and patches inside the ramparts on which various vegetable and fruit can be grown [16]. When visiting Antioch, Ibn Batuta ${ }^{6}$ mentioned about the ramparts as; "The ramparts are on a very steadfast location and characteristic as it was not seen in Damascus." [17].

Abd al-Mu'min al-Baghdadi ${ }^{7}$ [18] and Al-Himyari ${ }^{8}$ [19] gave information about the features of bastions in addition to ramparts;

"The ramparts around the city are one of the most interesting structures of the world. The length of the ramparts is 12 miles. The number of balconies on ramparts and bastions is 24 thousand. There are 360 bastions. Each bastion has paths to be connected with each other and also has rooms for horses and men to stay. There is also connection between the room for horses at the bottom floor and the room for men at the top floor. Each bastion has an iron gate just like a castle".

\section{B. The Magnificence of Antioch, the City of God or the Queen of Cities}

Antioch, which was named as "The Queen of the East" in the ancient ages, being as the favorite city of the emperors in the Roman times with its population over hundreds thousand. The famous historian, lived in fourth century, Ammianus Marcellinus stated that "...no city in the world can outcompete this city about the fertility of his lands and also the richness in trade". It is understood that the traveler agreed that Antioch was the most majestic city of the age in 11 th or $12^{\text {th }}$ century. It is also understood that the architectural structures, location, nature, castle, weather, water and fertile lands of Antioch, had impressed the travelers when they had visited Antioch even after the wearing effects of wars and earthquakes. According to AlQazwini [14] and Al-Iskandari ${ }^{9}$ [20] Antioch was one of the strongest cities of that time. The people of Antioch were aware of the magnificence and significance of their city and they were very proud of it. Al-Qazwin ${ }^{10}$, reflects the beauties of Antioch as; "Antioch is one of the leading cities of Damascus region, around the sea of Rome. Its characteristic features are the freshness of its water, pleasant weather and a chaste city. There are fields and gardens in the when you enter the city. " [14].

According to Abd al-Mu'min al-Baghdadi ${ }^{11}$ as well, Antioch was one of the most important city of Damascus region [18]. When describing Antioch, Al-Baghdadi used the words "elegance and beauty".

Whereas Al-Tabari ${ }^{12}$ stated that Antioch was the best city of the Damascus region [21], Al-Bakri ${ }^{13}$ added that Antioch was the most important city in the world, in his own sentences; "In all around the Arab world, there was Antioch

\footnotetext{
${ }^{5}$ Al-Idrisi, pp. 645

${ }^{6}$ Ibn Batuta, v. 1, pp. 91

${ }^{7}$ Al-Baghdadi, pp. 125

${ }^{8}$ Al-Himyari, pp. 38-39

${ }^{9}$ Al-Iskandari, v. 1, pp. 142

${ }^{10}$ Al-Qazwini, pp. 100-101

${ }^{11}$ Al-Baghdadi, v.1 pp. 125

${ }^{12}$ Al-Tabari, v1. pp. 124

${ }^{13}$ Al-Bakri, v.1, pp. 200
}

even before Damascus. There is no other city like this one in Muslim countries or in Roman Empire." [22].

Another traveler who emphasized on the chasteness and elegance of the city is Al-Himyari ${ }^{14}$ [19]. Al-Himyari reflected his observation briefly as:

It is a magnificent city by the city in Damascus region. Among all Arabs, whatever exists before Damascus was in Antioch. There is no city like that neither in Islam nor Roman regions. It is located in a generous location and it cannot be found such a chaste city in Damascus region. .... There are gardens and fields, buildings and inns inside the ramparts.

Antioch is very important for Christianity as well. This was also determined by the travelers of that time. Al-Bakri ${ }^{15}$ stated that since it was very significant for Christians, it was also called the city of God [22]. He explains as follows.

"Being the city where the Christianity was revealed for the first time and also the throne of Petrus and Simon was located, the Christians called the city "The City of God" or "The City of the King". ",

Al-Mas udi $^{16}$ [13] also explained this feature of Antioch with similar sentences as;

"Antioch has a lot of interesting buildings and it is a magnificent city. Christians named the city as "The City of God". Also Antioch is called "The City of King" since the Christianity started spreading from here."

Ibn Batuta ${ }^{17}$ stated that [17] "Antioch is a majestic and noble city and has many beautiful houses and buildings. The city is also full of trees".

\section{The Churches of Antioch}

Antioch is the city where the name "Christianity" was used for the very first time and the St.Pierre Chruch in the city is one of the most important historical churches of the Christian world. It is in the recommendation list of UNESCO World Heritage. The church is also accepted as a pilgrimage location for the Christians and every year in $29^{\text {th }}$ of June, The Catholic Church holds a mass in this church ${ }^{18}$. Although there are just a couple churches still existing in Antioch today, it is understood that during the times that these Arab travelers had visited, there were remarkable number of churches. Antioch is not only the place of churches but also one of the five patriarch centers that the Christians were affiliated to since the $7^{\text {th }}$ century Al-Idrisi ${ }^{19}$ [16]. The others are Rome, Alexandria, Jerusalem and Istanbul. After the fourth century, the fame of Antioch in Christian world was increased and became the second religious center after Rome. It became one of the five great patriarchate for Orthodox Christians.

Al-Qazwini ${ }^{20}$ [14] stated the number and the features of these churches as; "There are numerous churches. All of

\footnotetext{
${ }^{14}$ Al-Himyari, pp. 38-39

${ }^{15}$ Al-Bakri, v. 1, pp. 200

${ }^{16}$ Al-Masudi v. 2, pp. 199

${ }^{17}$ Ibn Batuta, v. 1, pp. 91

${ }^{18} \mathrm{http}: / /$ whc.unesco.org/en/tentativelists/5613/

${ }^{19}$ Al-Idrisi, v. 2, p 751

${ }^{20}$ Al-Qazwini, pp. 100-101
} 
these churches were adorned with gold and silver and constructed with colored glass and grainy marble."

Al-Mas 'udi ${ }^{21}$ mentioned the important churches of Antioch by their names [13];

There is church in Antioch called Pavlus Church. This is Eli Bab Faris church which is also known as Al Beragis Monastery. Another one is Aşmunit church where prayers and big religious festivals were held, and another one is Barbara Church; there is also Meryem Church which one of the most magnificent church in the world from the aspects of height and strength.

The architectural specifications of the churches were described by Yaqut al-Hamawi ${ }^{22}$ as follows [15]; "there are lots of churches made of golden, silver, colorful glass and marble which are architecturally unique." Yaqut alHamawi $^{23}$ emphasized one of the churches in the Antioch city center [15]. That was not only a church but also an education center. Al-Hamawi described this church and its features as follows [15];

"They sell qisyan (clothing made of flax or silk) in the city center. The building they sell these clothes is located in the place where the son of King was resuscitated. The length of this building is 100 steps and the width is 80 steps. There is a church on this building constructed on the pillars. This building was surrounded with porticos and the governor of the city lives there and also languages were taught."

\section{The Abundance of Water and Hammams}

Another feature of Antioch that attracted the attention of travelers visited this city was the abundance of water and hammams. The importance of Damascus among Arab people was very obvious. When they were describing a city or telling its beauties, the Arab travelers had always compared it with Damascus. About the abundance of water Al-Mas 'udi ${ }^{24}$ stated that [13] "The freshness of the water in Antioch can be figured out looking at their livestock." And Al-Himyari ${ }^{25}$ said [19]; "The water of Antioch is abundant enough to fill all the streets".

An Arab traveler Al-Idrisi ${ }^{26}$, provided more detail about this [16].

Antioch is a beautiful and fertile city which can even outcompete Damascus. There are water facilities in the city which is sourced from outside and is being distributed to streets, markets, roads, and villas of the city...

In the gardens and fields located in the entrances of the ramparts, there are various kinds of grains and pulses and other fertile products. There is also a river in Antioch which is called Orontez (Asi).

Yaqut al-Hamawi ${ }^{27}$ presented more details on this topic as well [15].

\footnotetext{
${ }^{21}$ Al-Masudi v.2, pp. 199

${ }^{22}$ Yaqut al-Hamawi, v. 1, pp. 267

${ }^{23}$ Yaqut al-Hamawi, v. 1, pp. 267

${ }^{24}$ Al-Masudi, v.1, pp. 303

${ }^{25}$ Al-Himyari, pp. 38-39

${ }^{26}$ Al-Idrisi, pp. 645, 646, 647

${ }^{27}$ Yaqut al-Hamawi, v. 1, pp. 267
}

Antioch, is a place of abundance with its chaste and beautiful ambiance, pleasant weather, delicious and vitalizing fresh water, and also various kinds of fruits. In his letter to Abu Hasan Hilal bin Muhsin al Sabi about Antioch, Ibn Batlan stated that "We started our journey from Aleppo to Antioch, the distance between them is a day and a night. As we traveled between these two cities, we have never seen a ruined or wrecked building. But the interesting part that the people of this region, grow wheat and barley under the olive trees. It is very easy to communicate with the villagers here and the foreign people coming from outside can stay here very safely.

Another traveler talking about the beauty of water and hammams in Antioch is Al-Qazwini ${ }^{28}$ who reflected his thoughts as [14].

"Its hammams are very beautiful and they have the most delicious and the best water in the world, they burn woods obtained from myrtle trees."

Like the other travelers, Al-Baghdadi ${ }^{29}$ also mentioned about the abundance of water, various fruits and fertility of Antioch [18].

The abundance of water in Antioch led the hammams become very famous. The travelers could use these hammams for free. Al-Mas 'udi provided information about the buildings of hammams [13];

"This hammam in Antioch is on the right side of the mosque and built with bricks and rocks. It is a remarkable building. The most important specification of this building is that when the moon rises one a year, it appears on one of the gates of this building.

Yaqut al-Hamawi ${ }^{30}$ also mentioned the beauty of hammams as [15]; "The hammams in this city has such a fresh and pleasant taste that it is not possible to find something like that anywhere else in the world. The wood from the myrtle tree is burnt in these hammams. The travelers can use those hammams for free."

\section{E. Habib Al-Najjar and the Mosque}

It is known as the first Mosque to be built in Anatolia. Habib Al-Najjar Mosque was built on the ruins of a pagan temple from the Roman Age. There are tombs which are told to be belonging to Yuhanna, Pavlos and Petrus who were the apostles of Jesus. The importance for the Muslims comes from the story which is told in the Koran in surah of Yasin. Al-Mas'udi [13]; Al-Bakri ${ }^{31}$ [23] and Abd alMu'min Al-Baghdadi ${ }^{32}$ [18] and Ibn Batuta ${ }^{33}$ [17] are the travelers who stated that Habib Al-Najjar's tomb is located here. However Al-Qazwini ${ }^{34}$ also stated that both Habib AlNajjar's and Zachariah's -the son of John have their tombs here [14].

\footnotetext{
${ }^{28}$ Al-Qazwini, pp. 100-101

${ }^{29}$ Al-Baghdadi, v.1 pp. 125

${ }^{30}$ Yaqut al-Hamawi, v. 1, pp. 267

${ }^{31}$ Al-Bakri, v.1, pp. 200

${ }^{32}$ Al-Baghdadi, v.1 pp. 125

${ }^{33}$ Ibn Batuta, v.1, pp.91

${ }^{34}$ Al-Qazwini, pp. 102
} 


\section{F. The Trade in Antioch}

Besides the architecture, Arab traveler also described the market and products of Antioch. Owing to its location, Antioch is in the center of intersecting roads and also on a very fertile plain. There were a lot of inns which are survived till today. It is understood that they were especially developed in weaving. Abd al-Mu'min al-Baghdadi, satisfied with just telling trade was very wide spread in Antioch [18]. Al-Mas'udi mentioned that many people make their living with weaving of cloth called kısyan; AlIdrisi $^{35}$; also mentioned about the weaving as "There are one piece clothing weaved in Antioch which are very strong." [16] However Al-Himyari ${ }^{36}$ [19] explained what was exactly this weaving "They produce very durable horse cloths in Antioch."

Another traveler; Al-Qazwini ${ }^{37}$ who have visited this qisyan market described it in more details [14];

There is qisyan market in the center of the city. There are many people working and making their living in this market. There are also 10 clerks who record the products being sold.

Yaqut al-Hamawi ${ }^{38}$ also mentioned about the weaving of qisyan and the place where it was produced and he also added the dimensions of this building [15].

"Qisyan (clothes made of flax or silk) is being sold in the center of the city. The building where they sell these clothes is also the place where the son of the King was resuscitated. The length of this building is 100 steps and the width is 80 steps. There is a clock on one of the walls of this building which works day and night and divides the day to 12 hours. This clock is one of the most interesting clocks in the world."

\section{G. The Periapt of Antioch}

In the ancient times, there were various periapts to protect the cities from diseases, troubles, attacks and harmful animals. Being one of the important cities of that era, a periapt was prepared for Antioch to protect from snakes, centipedes and ants. Al-Qazwini ${ }^{39}$ [14], mentioned about a periapt that he quotes from Al-Mas 'udi's [13] travel book. This periapt was placed in the ramparts of Antioch. However, due to the curiosity of people, this periapt had lost its features;

"When someone extends his hand to outside of the ramparts, his hand is covered with insects but then when he pushes back his hand into the ramparts, insects are gone. This was true until they break apart a marble pillar and found a copper box inside and there were some copper insects inside this box. After they break apart this pillar, the situation of the city being free from insects was gone. Today in Antioch there are lots of insect and mice that the cats cannot handle."

\footnotetext{
${ }^{35}$ Al-Idrisi, v. 2, pp. 751

${ }^{36}$ Al-Himyari, pp. 38-39

${ }^{37}$ Al-Qazwini, pp. 101

${ }^{38}$ Yaqut al-Hamawi, v. 1, pp. 267

${ }^{39}$ Al-Qazwini, pp. 101
}

\section{CONCLUSION}

In the works that has been the subject of this study; the travelers who had visited Antioch usually had a positive impression. Almost all of them emphasized that Antioch was an important city. Antioch had started to lose its magnificence and importance during the Roman Empire gradually. But the traces of that magnificence have not completely disappeared yet.

The ramparts were the most remarkable building for the travelers. Almost all travelers mentioned about the ramparts that surrounded the city and described their features. Besides, the abundance of water and its natural flow in the streets of the city was another attention grabbing aspect of the city. The architecture of the churches and hammams and the freshness of their water are also mentioned as an impressive feature. Burning the woods of myrtle tree in hammams also attracted the attention of travelers.

Another important feature of Antioch that is understood from the travel books is that the people of Antioch were tolerant and open for communication and people felt themselves comfortable and safe in this city.

In the era that above mentioned travelers had visited Antioch, the city had been still preserving its importance for Christians. It is one of the five patriarchs of Orthodox world. As it is understood from the travel books Antioch was the city where weaving and trade was conducted. Although Arab travelers have not provided much information about that, a few of them wrote that though clothes were weaved.

\section{REFERENCES}

[1] G. Downey, A History of Antioch in Syria from Seleucus to the Arap Conquest, Princeton, New Jersey: Princeton University Press, 1961.

[2] P. Kloeg, Antioch the Great: Population and Economy of Secondcentury Antioch, Leiden, Netherland: Leiden University History, Leiden Univ., 2013.

[3] A. Gunduz, I. Gokhan, S. Hatipoglu, and G. Bahadir, Hatay Tarihi, Hatay Valiligi Anit Matbaa, 2013.

[4] Permanent Delegation of Turkey to UNESCO. (April 2011). Hatay, St. Pierre Church. United Nations Educational, Scientific and Cultural Organization. [Online]. http://whc.unesco.org/en/tentativelists/5613/

[5] S. Maden, "Türk Edebiyaiında Seyahatnameler Ve Gezi Yazilari," A.Ü. Türkiyat Arastırmalari Enstitusu Dergisi, vol. 37, pp. 147-158, 2008

[6] H. Doganay, Cografyaya Giris, Çizgi Kitabevi, Konya, 2000.

[7] E. Eskikurt, "Tarihî cografya calişmalarinin metodolojisi konusunda genel bir degerlendirme," Marmara Cografya Dergisi, vol. 11, pp. 39-63, 2005.

[8] A. Islam, "The contribution of Muslims to science during the middle Abbasid period (750-945)," Revelation and Science, vol. 1, pp. 39-56, 2011.

[9] M. Sala. (December 2014). Geography. EOLSS Publishers Co Ltd. [Online]. vol. I. Available: http://www.eolss.net/samplechapters/c01/e6-14-01-01.pdf

[10] C. Kondoleon, Antioch: The Lost Ancient City. Worcester, Mass, Leiden University, Netherland, 2000.

[11] H. Demircioglu, Roma Tarihi, Ankara: T. T. K. Yayinlari, 1998, vol. I.

[12] A. Yildirim and H. Simsek, Nitel Arastirma Yontemleri, Ankara: Seckin Yay, 2008

[13] Al-Mas'udi and Abu 1-Hasan 'Ali ibn Husayn ibn 'Ali, Muruj alDhahab wa-Ma'adin al-Jawhar, M. Muhyi al-Din 'Abd al-Hamid, Ed., Dar al-Fikr, Beirout, Lebanon, 1973, vol. 1-2.

[14] Z. al-Qazwini, Athar al-bilad 'Aja'ib al-makhluqat, F. Wüstenfeld, Ed., Göttingen, 1849.

[15] Y. al-Hamawi, Kitab mu'jam al-buldan, reprinted Dar Sadeer lilTTiba'ah wa-al-Nashr, Beirout, Lebanon, 1977.

[16] Al-Idrisi and A. A. A. M. al-Qurtubi al-Hasani al-Sabti, Kitab Nuzhat Al-Mushtaq, reprinted by Maktab al Saqafat al Diyniyye, Cairo, Egypt, 2002. 
[17] I. Batuta and A. 'Abd al-Lah M. ibn 'Abd al-Lah 1-Lawatī Țangi, alRihla, S. M. Abd al Muneem al Arian and M. al Qassas, Eds., Dar al Ihya al uloom, Beirout, Lebanon, 1987.

[18] Al-Baghdadi, S. ad-Din A. al-Mu'min A. al Haqq, Marasid al-Ittila ala Asma al-Amkina wa al-Biqa, A. M. al Bacawi, Ed., Dar al-Ma'rifa, Beirout, Lebanon, 1954.

[19] Al-Himyari and M. bin A. al-Mun'eem, Kitab al-Rawd al-Mitar, I. Abbas, Ed., Beirout, Lebanon, 1975.

[20] Al-Iskandari and N. bin A. al-Rahman, Amkinah wal-Miyah wal alJibal wa-al-athar wa-nahwaha, King Faisal Center for Research and Islamic Studies, Saudi Arabia: Riyadh, 2004.

[21] Al-Tabari and A. Ja'far M. I. Jarir, Tarikh al-Rusul Wa-l-Muluk, M. A Al F. Ibrahim, Ed., Dar al-Ma'arif, Cairo, Egypt, 1979.

[22] Al-Bakri al Andalousie, Mu'jam ma Ista'jam min Asma' al-Bilad wa-l Mavadi, M. al Saqa and A'lam al Kitab, Eds., Bairout, Lebanon, 1954.

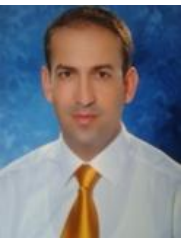

Abdullah Balciogullari was born in Hatay, Turkey in 1973. He got his bachelor degree in the Geography Department at Ankara University in 1998 in Ankara/ Turkey and he wanted to study on instruction of geography he has received his master degree in the Curriculum and Instruction Department at Cukurova University in 2004 in Adana, Turkey. He has got his doctoral degree in the same department of same university in 2011. He concentrates his studies on historical geography. At the moment he has been working as an assistant professor at Çukurova University, Social Studies Education Department in Adana, Turkey. One of his study fields is Arabic manuscripts. Currently he is working on Arabic manuscripts about geography and itineraries. 